\title{
Article \\ Visualization of Slag Data for Efficient Monitoring and Improvement of Steelmaking Slag Operation in Electric Arc Furnaces, with a Focus on MgO Saturation
}

\author{
Marcus Kirschen
}

check for updates

Citation: Kirschen, M. Visualization of Slag Data for Efficient Monitoring and Improvement of Steelmaking Slag Operation in Electric Arc Furnaces, with a Focus on $\mathrm{MgO}$ Saturation. Metals 2021, 11, 17. https: / dx.doi.org/10.3390/ met11010017

Received: 2 December 2020 Accepted: 22 December 2020 Published: 24 December 2020

Publisher's Note: MDPI stays neutral with regard to jurisdictional claims in published maps and institutional affiliations.

Copyright: (c) 2020 by the author. Licensee MDPI, Basel, Switzerland. This article is an open access article distributed under the terms and conditions of the Creative Commons Attribution (CC BY) license (https: / / creativecommons.org/ licenses/by/4.0/).
Thermal Process Engineering, University of Bayreuth, Universitätsstrasse 30, D-94557 Bayreuth, Germany; marcus.kirschen@uni-bayreuth.de

\begin{abstract}
Frequent slag sampling and analysis is still the most common method used to investigate and improve slag operation in electric arc furnaces (EAFs) for low-alloyed carbon steelmaking. An $\mathrm{MgO}$ saturation diagram for EAF slags was derived from phase equilibrium calculations in the system $\mathrm{CaO}-\mathrm{MgO}-\mathrm{FeO}-\mathrm{SiO}_{2}-5 \% \mathrm{Al}_{2} \mathrm{O}_{3}$ to provide monitoring and interpretation of the slag data with respect to control of $\mathrm{MgO}$ saturation, $\mathrm{FeO}$ reduction, dissolution from the $\mathrm{MgO}$-based refractory lining, and unusual losses of repair mixes. Examples from 14 industrial EAFs are given.
\end{abstract}

Keywords: electric arc furnace; process slag; saturation model; process improvement

\section{Introduction}

Steelmaking based on the melting of steel scrap and other ferrous raw materials in electric arc furnaces (EAFs) contributed approximately 523 million tons, i.e., 28\%, of global steel production in 2019 [1]. The share of EAF steelmaking is growing globally due to increasing steel scrap recycling capacity in developed economies and very flexible production regarding the use of ferrous raw materials or alloys with volatile market demand (examples in Figure 1). Recycling of steel scrap and the use of direct reduced iron (DRI) in EAFs are important options to control the specific $\mathrm{CO}_{2}$ emissions of the global steel industry.
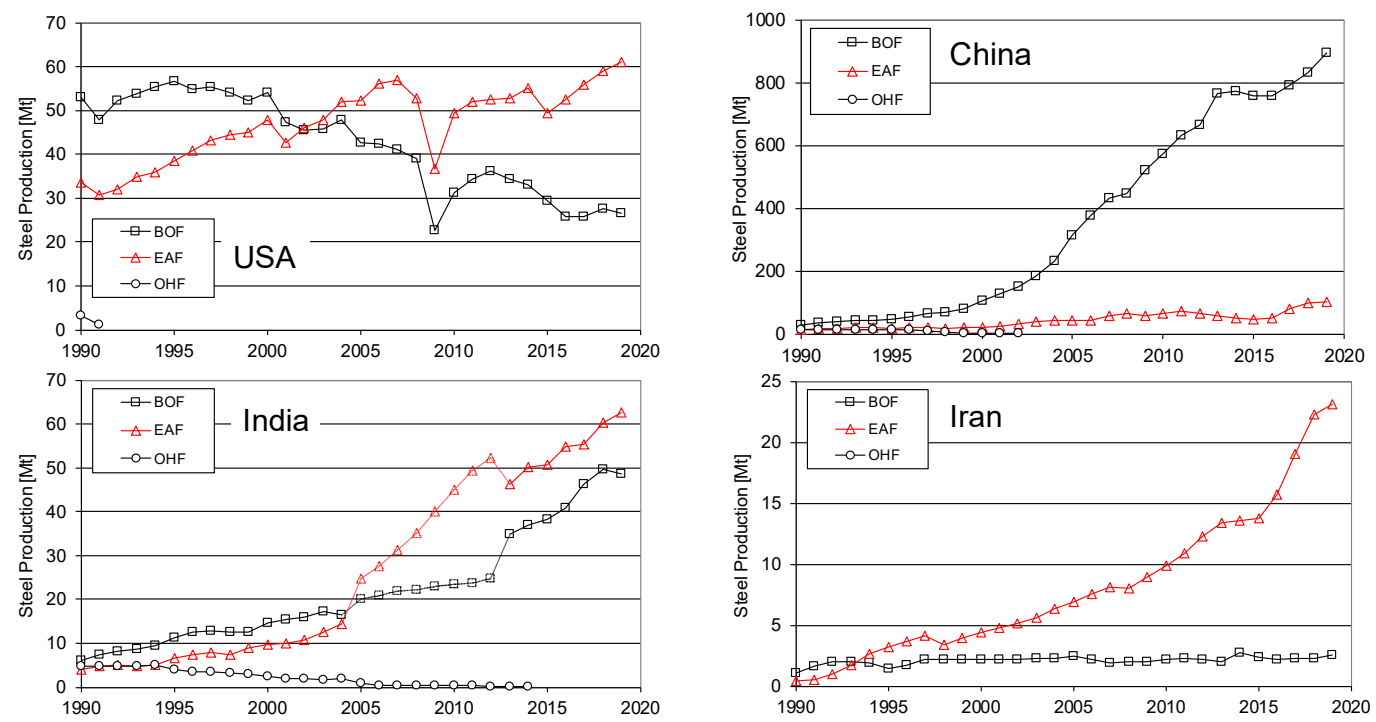

Figure 1. Four examples of electric arc furnace (EAF) steel production on different levels in the global steel industry (basic oxygen furnace, BOF; open hearth furnace, OHF); data from World Steel Association [1]. 
Process control and optimization in EAFs with various designs (e.g., alternating or direct current EAFs, and EAFs with scrap preheating shafts or conveyors for continuous charging of scrap and DRI) requires reliable data from the inside, which are still challenging to obtain. The available data are from regular steel sample analysis and temperature, C content, and oxygen measurements at the final process stage and, commonly, slag samples before tapping. The importance of appropriate slag operation in EAFs was realized early for optimized efficiency of energy transfer from the electric arcs by foaming slag ([2] and references therein). Pretorius and others provided helpful guidelines and models for slag operation in basic oxygen furnaces (BOFs), EAFs, and ladles during steel refinement [3-5]. Frequent slag sampling and analysis has been implemented as an efficient process monitoring tool to ensure efficient operation under foaming slag conditions with an appropriate slag viscosity, requiring control of the slag composition at $\mathrm{MgO}$ saturation.

\subsection{Slag Operation in EAFs}

Slag formers such as lime, dolomitic lime, or doloma are charged with steel scrap or alternative ferrous raw materials such as DRI in order to dissolve the oxidation products and residues of the steel scrap, including $\mathrm{SiO}_{2}, \mathrm{Al}_{2} \mathrm{O}_{3}, \mathrm{Cr}_{2} \mathrm{O}_{3}, \mathrm{P}_{2} \mathrm{O}_{5}$ (e.g., [6]), and $\mathrm{TiO}_{2}$. $\mathrm{FeO}$ is partially reduced in the slag layer by mixing with carbon-containing steel melt or by injecting coal or carbon fines (e.g., [7]). The efficiency of energy transfer from the electric arcs to the molten metal is increased when submerged in a foaming slag layer with increased volume (e.g., [8,9]) that is stable at a certain range of apparent viscosity, surface tension, and sufficient $\mathrm{CO}$ gas generation (e.g., [10-12]). The viscosity of the basic EAF slag is increased to the required range using finely dispersed periclase crystals, i.e., when the slag composition is $\mathrm{MgO}$ saturated [4,5]. Consistently, optimum slag foaming is observed at EAF slag compositions with basicity $\mathrm{B}_{2}=\mathrm{x}_{\mathrm{CaO}} / \mathrm{x}_{\mathrm{SiO} 2} \approx 2$ [4,5], i.e., heterogeneous slag foaming $[9,13]$, in order to compensate the viscosity decreasing effect of FeO (e.g., [14]). The complex behavior of $\mathrm{FeO}$ in slag foaming was clarified by considering the composition dependence of the $\mathrm{Fe}^{3+} / \mathrm{Fe}^{2+}$ ratio on the surface tension [15]. Other basicity concepts comprise the decreasing influence of $\mathrm{Al}_{2} \mathrm{O}_{3}$ on basic slag properties, e.g., $\mathrm{B}_{3}=$ $\mathrm{x}_{\mathrm{CaO}} /\left(\mathrm{x}_{\mathrm{SiO} 2}+\mathrm{x}_{\mathrm{Al} 2 \mathrm{O} 3}\right)$ or $\mathrm{B}_{4}=\left(\mathrm{x}_{\mathrm{CaO}}+\mathrm{x}_{\mathrm{MgO}}\right) /\left(\mathrm{x}_{\mathrm{SiO} 2}+\mathrm{x}_{\mathrm{Al} 2 \mathrm{O} 3}\right)$.

\subsection{MgO Saturation of EAF Slags_-Implications for the Refractory Lining Lifetime}

Besides operating the process slag at good foaming slag conditions, $\mathrm{MgO}$ saturation helps to minimize corrosion of the $\mathrm{MgO}$-based hearth and $\mathrm{MgO}-\mathrm{C}$ sidewall lining. At undersaturated slag compositions, i.e., at $\mathrm{MgO}$ activity of $<1, \mathrm{MgO}$ is dissolved from the $\mathrm{MgO}$-based hearth and hearth repair mixes or from the $\mathrm{MgO}-\mathrm{C}$-based sidewall, depending on the process temperature and duration (e.g., [16]), until MgO saturation of the slag is achieved. High-FeO slags provide increased corrosion potential to the $\mathrm{MgO}$ lining by the degradation of periclase to $\mathrm{Mg}$-wüstite $[17,18]$ and lowered slag viscosity.

The loss of $\mathrm{MgO}$ from the lining by spalling, e.g., due to thermal shocks, or $\mathrm{MgO}$ loss from repair layers results in increased $\mathrm{MgO}$ content of the slag, either dissolved at $\mathrm{MgO}$-undersaturated compositions or as dispersed solid periclase at $\mathrm{MgO}$-oversaturated compositions, indicating unwanted and unnecessarily high $\mathrm{MgO}$ losses.

Depending on the $\mathrm{MgO}$ content and the mass ratio of the charged slag formers, the EAF process is started with an $\mathrm{MgO}$-undersaturated slag composition in most cases. The amount of dissolved $\mathrm{MgO}$ in the slag from the beginning of heating until tapping is related to the $\mathrm{MgO}$ losses from the lining, due to the $\mathrm{MgO}$ mass balance [19]. Therefore, it is recommended to apply $\mathrm{MgO}$-containing slag additives or modifiers as early as possible in order to decrease the corrosion potential of the process slag [4,5,19-22]. This keeps the $\mathrm{MgO}$ activity in the slag at high levels, ideally close to 1 . An increased mass of hot heel is recommended in order to provide a larger slag mass for buffering increased $\mathrm{SiO}_{2}$ input, for example, due to DRI [18]. Models of $\mathrm{MgO}$ saturation are crucial to optimize the input of slag formers and slag operation in EAF steelmaking. 


\subsection{MgO Saturation Models for Steelmaking Slags}

Some proposed saturation models determine the $\mathrm{MgO}$ concentration as a complex function of the slag composition and temperature, based on saturation experiments on various metallurgical process slags, e.g., [4,23-27]. Pretorius and Carlisle [4], Park and Lee [24], and Tayeb et al. [26] provided the $\mathrm{MgO}$ saturation as a function of slag basicity for EAF slags or ladle slags. The typical MgO saturation concentrations in EAFs are approximately $9 \% \mathrm{MgO}$ in EAF slags with basicity $\mathrm{B}_{2}=2$ [4].

Another approach is the derivation of saturation diagrams from published phase diagrams in the $\mathrm{CaO}-\mathrm{MgO}-\mathrm{FeO}-\mathrm{SiO}_{2}-\mathrm{Al}_{2} \mathrm{O}_{3}$ system $[4,5]$, or the application of phase equilibrium software [18,19,28-31] such as Factsage [32] to calculate the required $\mathrm{MgO}$ saturation diagrams in the $\mathrm{CaO}-\mathrm{MgO}-\mathrm{FeO}-\mathrm{SiO}_{2}-\mathrm{Al}_{2} \mathrm{O}_{3}$ system for ladle and $\mathrm{EAF}$ slags. In all cases, a formula for a restricted range of slag compositions or an $x-y$ diagram with a constraint slag composition, e.g., for a constant basicity, was chosen to determine the required $\mathrm{MgO}$ saturation for the particular process slag composition. An overview on published $\mathrm{MgO}$ saturation models in steelmaking is given in Table 1.

Table 1. Published models of $\mathrm{MgO}$ saturation of steelmaking slags.

\begin{tabular}{|c|c|c|c|}
\hline Author(s) & Target Function & Metallurgical Unit & Variables \\
\hline Schürmann and Kolm (1986) [23] & MgO saturation & BOF, EAF & $\mathrm{CaO}, \mathrm{SiO}_{2}, \mathrm{FeO}, \mathrm{Al}_{2} \mathrm{O}_{3}, \mathrm{MnO}, \mathrm{T}$ \\
\hline Park and Lee (1996) [24] & $\mathrm{MgO}$ saturation & Ladle & $\mathrm{B}_{3}$ basicity \\
\hline Pretorius and Carlisle (1999) [4] & $\mathrm{MgO}\left(\right.$ and $\mathrm{C}_{2} \mathrm{~S}$ ) saturation & EAF & $\mathrm{FeO}, \mathrm{B}_{2}$ and $\mathrm{B}_{3}$ basicity \\
\hline Park (2001) [25] & $\mathrm{MgO}$ saturation & $\mathrm{BOF}$ & $\mathrm{CaO}, \mathrm{SiO}_{2}, \mathrm{FeO}, \mathrm{Fe}_{2} \mathrm{O}_{3}$ \\
\hline Brüggmann and Pötschke (2011) [28] & $\mathrm{MgO}$ saturation & Ladle & $\mathrm{CaO}, \mathrm{SiO}_{2}, \mathrm{Al}_{2} \mathrm{O}_{3}$ \\
\hline Tayeb et al. (2015) [26] & $\mathrm{MgO}$ saturation & BOF, EAF & $\mathrm{CaO}, \mathrm{SiO}_{2}, \mathrm{Al}_{2} \mathrm{O}_{3}, \mathrm{FeO}$ \\
\hline
\end{tabular}

All these models are useful to calculating the $\mathrm{MgO}$ saturation of particular slag compositions, either for laboratory investigations or for average values of industrial data sets. Slag compositions in industrial EAFs, however, span a wider range in the composition space $\mathrm{CaO}-\mathrm{MgO}-\mathrm{FeO}-\mathrm{SiO}_{2}-\mathrm{Al}_{2} \mathrm{O}_{3}$ due to variations in raw materials and process conditions. Instead of pointwise assessment of average $\mathrm{MgO}$ saturation levels, it is of interest to visualize and investigate the slag compositions of large datasets from industrial EAFs with respect to the complex $\mathrm{MgO}$ saturation surface in multicomponent space.

\section{Calculated $\mathrm{MgO}$ Saturation Surface in the System $\mathrm{CaO}-\mathrm{MgO}-\mathrm{FeO}-\mathrm{SiO}_{2}-5 \% \mathrm{Al}_{2} \mathrm{O}_{3}$}

The databases provided with the Factsage software package are today the best available representation of the binary, ternary, and quaternary diagrams of the $\mathrm{CaO}-\mathrm{MgO}-$ $\mathrm{FeO}-\mathrm{MnO}-\mathrm{SiO}_{2}-\mathrm{TiO}_{2}-\mathrm{Al}_{2} \mathrm{O}_{3}$ system. Recently, Tayeb et al. [26] verified the results from Factsage calculations with experimental $\mathrm{MgO}$ solubility data at typical slag compositions for BOFs and EAFs. Song et al. [18] presented valuable predictions from a recent Factsage database of $\mathrm{MgO}$ saturation concentrations in EAF slags for a significantly larger experimental dataset.

The saturation surface of $\mathrm{MgO}$ was calculated using the Factsage database in the system $\mathrm{CaO}-\mathrm{MgO}-\mathrm{FeO}-\mathrm{SiO}_{2}-\mathrm{Al}_{2} \mathrm{O}_{3}$ at $1600{ }^{\circ} \mathrm{C}$ and constant $5 \% \mathrm{Al}_{2} \mathrm{O}_{3}$ for EAF slags (Figure 2), thus neglecting the minor $\mathrm{TiO}_{2}$ and $\mathrm{Cr}_{2} \mathrm{O}_{3}$ slag components in carbon steelmaking slags. $\mathrm{MnO}$ [33] was also neglected here, suggesting the addition of a low amount of $\mathrm{MnO}$ to $\mathrm{FeO}$ when required for higher precision. The pseudo-ternary diagram in Figure 2 represents a slide section in the five-component space $\mathrm{CaO}-\mathrm{MgO}-\mathrm{FeO}-\mathrm{SiO}_{2}-\mathrm{Al}_{2} \mathrm{O}_{3}$ at $30 \%$ $\mathrm{CaO}$ and $5 \% \mathrm{Al}_{2} \mathrm{O}_{3}$. The chosen section is best suited to investigating the $\mathrm{MgO}$ saturation status of EAF slags for low-alloyed steel grades because (1) the $\mathrm{MgO}$ saturation field is represented to a maximum extent and (2) the calculated saturation lines are derived at compositions close to the slag data, in contrast to other $\mathrm{MgO}$ saturation figures (e.g., [4,5]). 


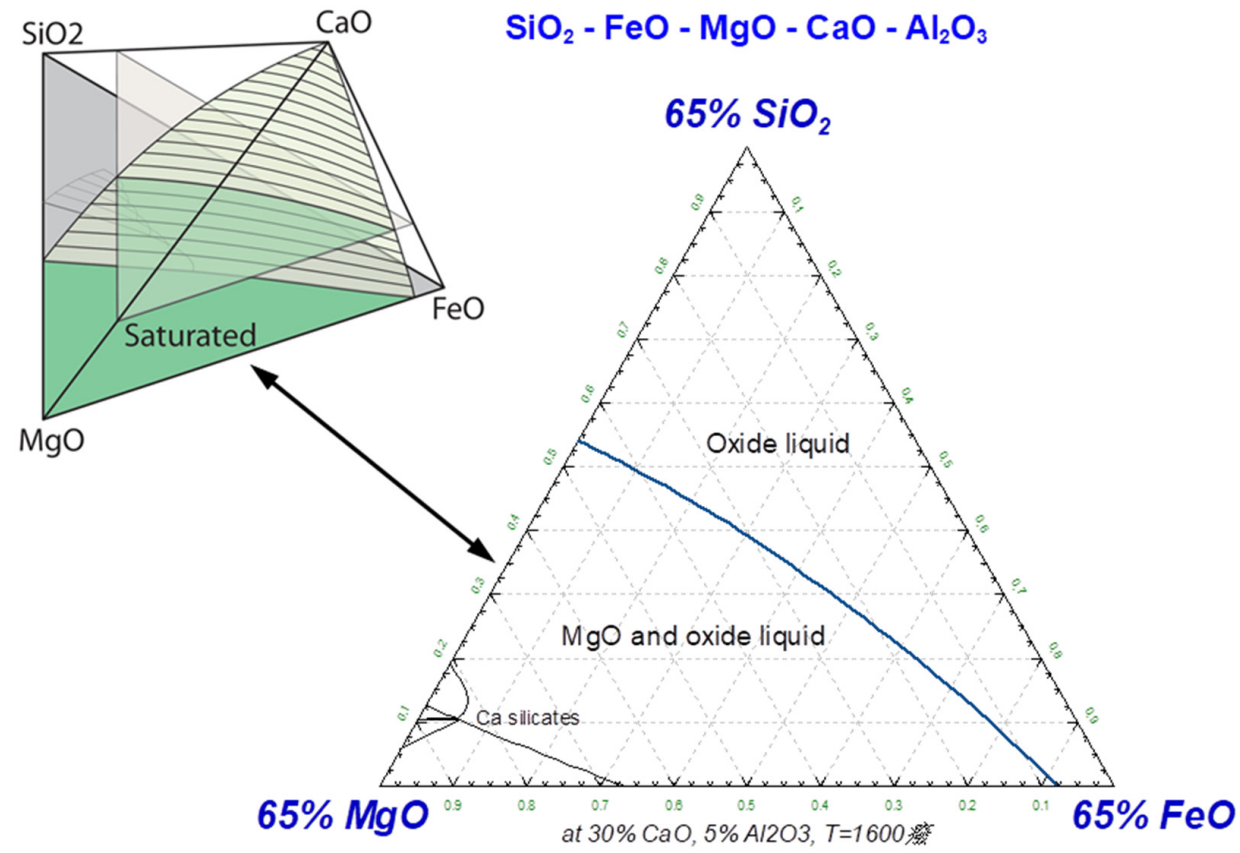

Figure 2. The calculated stability field of $\mathrm{MgO}$ periclase and $\mathrm{Ca}$ silicates on the pseudo-triangular plane at $30 \% \mathrm{CaO}$ and $1600{ }^{\circ} \mathrm{C}$ in the system $\mathrm{CaO}-\mathrm{SiO}_{2}-\mathrm{FeO}-\mathrm{MgO}-5 \% \mathrm{Al}_{2} \mathrm{O}_{3}$; all calculations from Factsage $^{\mathrm{TM}}$.

The most relevant saturation surface of EAF slags is the $\mathrm{MgO}$ saturation (Figure 2). Ca silicates are not stable in EAF slag compositions for low-alloyed carbon steelmaking at temperatures between $1550{ }^{\circ} \mathrm{C}$ and $1700{ }^{\circ} \mathrm{C}$ due to the $>20 \% \mathrm{FeO}$ and $3-10 \% \mathrm{Al}_{2} \mathrm{O}_{3}$ content (Figure 2).

In Figure 3, the $\mathrm{MgO}$ saturation lines are shown on the pseudo-ternary sections at $25 \%, 30 \%, 35 \%$, and $40 \% \mathrm{CaO}$ at $\mathrm{T}=1600{ }^{\circ} \mathrm{C}$, corresponding to the typical $\mathrm{CaO}$ range in EAF slags.

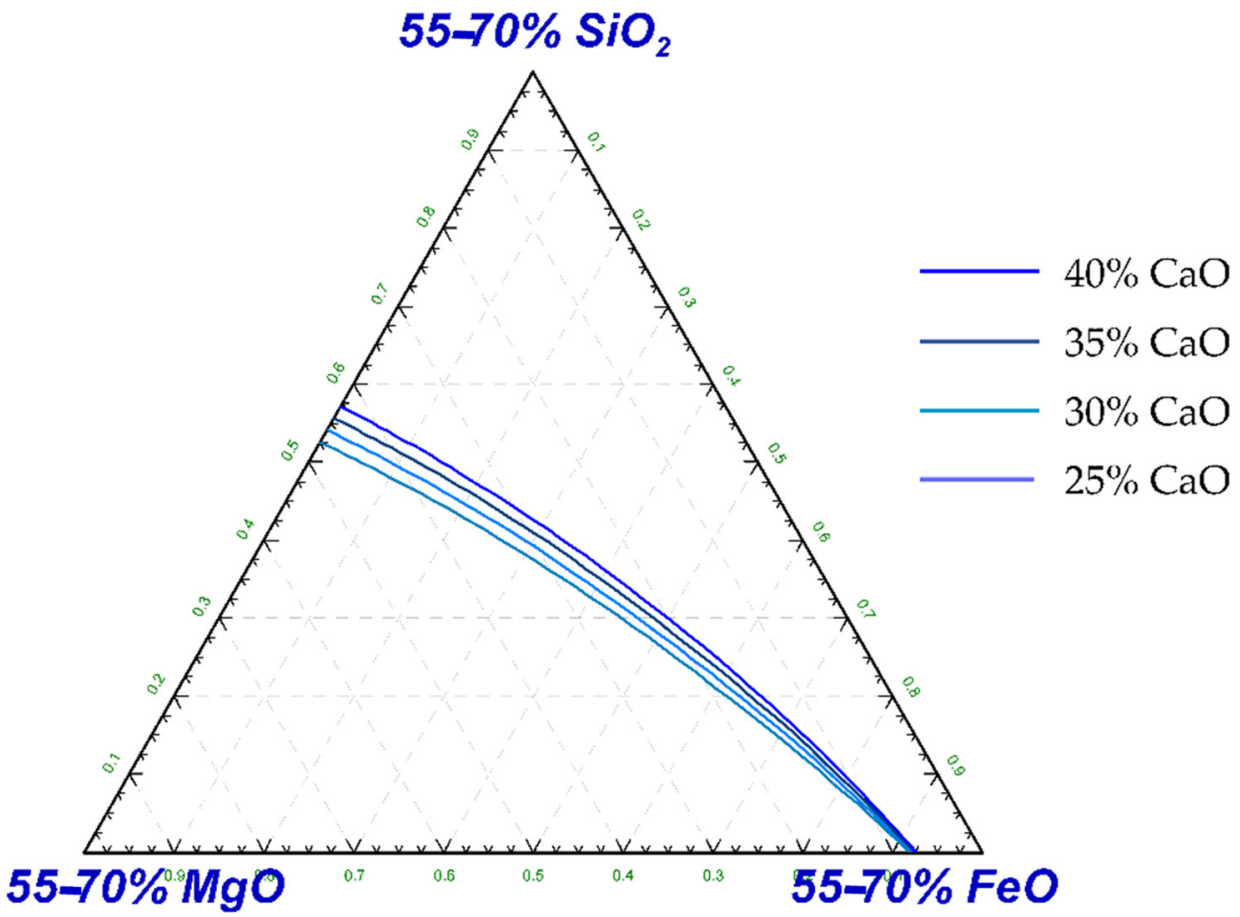

Figure 3. Projected $\mathrm{MgO}$ saturation lines in the pseudo-ternary sections at $25 \%, 30 \%, 35 \%$, and $40 \%$ $\mathrm{CaO}$ at $1600{ }^{\circ} \mathrm{C}$ in the system $\mathrm{CaO}-\mathrm{SiO}_{2}-\mathrm{FeO}-\mathrm{MgO}-5 \% \mathrm{Al}_{2} \mathrm{O}_{3}$; all calculations from Factsage ${ }^{\mathrm{TM}}$. 


\section{Application to Slag Analysis Data from Carbon Steelmaking EAFs}

The average slag compositions of 14 industrial EAFs for low-alloyed carbon steelmaking are given in Table 2. The product portfolio covered rebar and construction steel grades (8 EAFs) to special steel grades (2 EAFs). The applied raw materials were steel scrap (10 EAFs) and blends of steel scrap with DRI (4 EAFs). The sizes of the EAFs ranged from $60 \mathrm{t}$ to $>200 \mathrm{t}$ tap weight, located in nine countries worldwide. Slag samples were taken from the EAFs shortly before tapping and analyzed at the steelplant laboratory. Only mislabeled slag data, e.g., those from transport ladles (i.e., $\mathrm{FeO}<10 \%$ and $\mathrm{CaO}>45 \%$ ) or from raw materials (e.g., lime, DRI), were excluded from the data sets.

Table 2. Average slag compositions of 14 industrial EAFs for carbon steelmaking (in wt. \%).

\begin{tabular}{|c|c|c|c|c|c|c|c|c|c|c|c|c|}
\hline EAF & \# Data & $\mathrm{CaO}$ & $\mathrm{SiO}_{2}$ & $\mathrm{FeO}$ & $\mathrm{MgO}$ & $\mathrm{Al}_{2} \mathrm{O}_{3}$ & $\mathrm{MnO}$ & $\mathrm{Cr}_{2} \mathrm{O}_{3}$ & $\mathrm{TiO}_{2}$ & Total & \multicolumn{2}{|c|}{ Basicity } \\
\hline $1^{1}$ & 422 & 26.1 & 16.7 & 29.5 & 10.5 & 8.4 & 5.6 & 1.6 & 0.7 & 99.6 & $1.6^{5}$ & $1.5^{6}$ \\
\hline $2^{1}$ & 359 & 31.1 & 11.6 & 28.1 & 10.6 & 5.4 & 5.0 & 1.1 & 0.6 & 94.4 & $2.7^{5}$ & $2.5^{6}$ \\
\hline $3^{1}$ & 1216 & 25.6 & 13.5 & 34.5 & 11.3 & 6.0 & 6.4 & 2.5 & 0.4 & 100.7 & $1.9^{5}$ & $1.9^{6}$ \\
\hline $4^{1}$ & 471 & 25.6 & 12.1 & 29.7 & 9.4 & 14.5 & 4.6 & 2.1 & n.a. & 97.9 & $2.1^{5}$ & $1.3^{6}$ \\
\hline $5^{2}$ & 149 & 27.3 & 8.8 & 40.2 & 8.3 & 3.5 & 7.0 & 3.2 & 0.4 & 99.4 & $3.1^{5}$ & $2.9^{6}$ \\
\hline $6^{3}$ & 132 & 27.0 & 16.0 & 31.1 & 14.9 & 6.0 & 1.9 & n.a. & 1.2 & 98.0 & $1.7^{5}$ & $1.9^{6}$ \\
\hline $7^{1}$ & 186 & 26.0 & 11.9 & 34.9 & 10.0 & 9.1 & 3.9 & 3.2 & 0.5 & 99.5 & $2.2^{5}$ & $1.7^{6}$ \\
\hline $8^{1}$ & 843 & 35.5 & 17.4 & 16.9 & 14.7 & 7.0 & 6.0 & 1.4 & 0.4 & 98.8 & $2.0^{5}$ & $2.1^{6}$ \\
\hline $9^{1}$ & 296 & 28.8 & 12.2 & 30.7 & 9.6 & 6.1 & 8.0 & 2.9 & 0.5 & 99.3 & $2.4^{5}$ & $2.0^{6}$ \\
\hline $10^{1}$ & 63 & 29.8 & 11.6 & 34.7 & 10.4 & 5.1 & 8.5 & 1.8 & 0.4 & 102.2 & $2.6^{5}$ & $2.4^{6}$ \\
\hline $11^{3}$ & 325 & 28.5 & 19.4 & 33.9 & 9.7 & 3.2 & 0.2 & n.a. & 3.7 & 99.3 & $1.5^{5}$ & $1.7^{6}$ \\
\hline $12^{3}$ & 203 & 36.9 & 17.4 & 30.1 & 7.7 & 5.1 & 0.9 & n.a. & n.a. & 95.5 & $2.1^{5}$ & $2.0^{6}$ \\
\hline $13^{4}$ & 519 & 29.1 & 16.8 & 25.6 & 9.3 & 7.8 & 1.1 & n.a. & n.a. & 89.9 & $1.7^{5}$ & $1.6^{6}$ \\
\hline $14^{1}$ & 219 & 35.5 & 17.5 & 27.6 & 4.1 & 9.3 & 4.2 & n.a. & n.a. & 98.4 & $2.0^{5}$ & $1.4^{6}$ \\
\hline
\end{tabular}

${ }^{1}$ : rebar and construction steel grades, ${ }^{2}$ : specialty steel grades, ${ }^{3}: 1$ with direct reduced iron (DRI); ${ }^{4}:$ construction and specialty steel grades, DRI; \#: number of slag data; ${ }^{5}: \mathrm{B}_{2}=\mathrm{CaO} / \mathrm{SiO}_{2} ;{ }^{6}: \mathrm{B}_{4}=(\mathrm{CaO}+\mathrm{MgO}) /\left(\mathrm{SiO}_{2}+\mathrm{Al}_{2} \mathrm{O}_{3}\right)$, n.a.: not available.

Most EAF slags were set to a $B_{2}$ basicity of 1.9 to 2.4 , with only a few exceptions at lower basicity (EAFs 1, 6, 11, and 13) and a few at higher basicity (EAFs 2, 5, and 10). A higher basicity is required, e.g., to keep the $\mathrm{P}$ value of the tapped steel below strict limits (e.g., $[6,34])$.

EAF slag analysis data from various carbon steelmaking EAFs are plotted in the proposed saturation diagram in the system $\mathrm{CaO}-\mathrm{MgO}-\mathrm{FeO}-\mathrm{SiO}_{2}-5 \% \mathrm{Al}_{2} \mathrm{O}_{3}$ (Figure 3) in Figures 4-6, without any further data manipulation or data processing of the provided data. The EAF slag data represent multidimensional distributions at or near the $\mathrm{MgO}$ saturation.
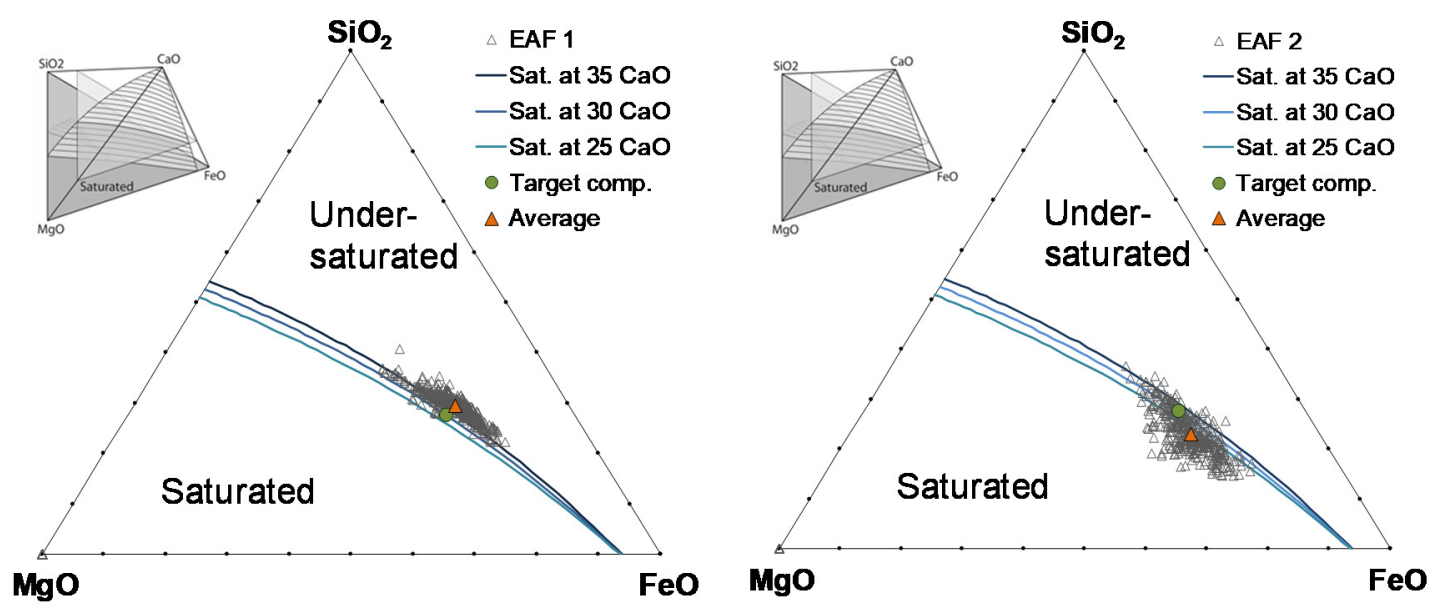

Figure 4. Distribution of slag analysis data from EAF heats for carbon steelmaking, in the system $\mathrm{CaO}-\mathrm{SiO}{ }_{2}-\mathrm{FeO}-\mathrm{MgO}-$ $5 \% \mathrm{Al}_{2} \mathrm{O}_{3}$; lines indicate $\mathrm{MgO}$ saturation at $25 \%$ to $35 \% \mathrm{CaO}$ and $1600{ }^{\circ} \mathrm{C}$. 

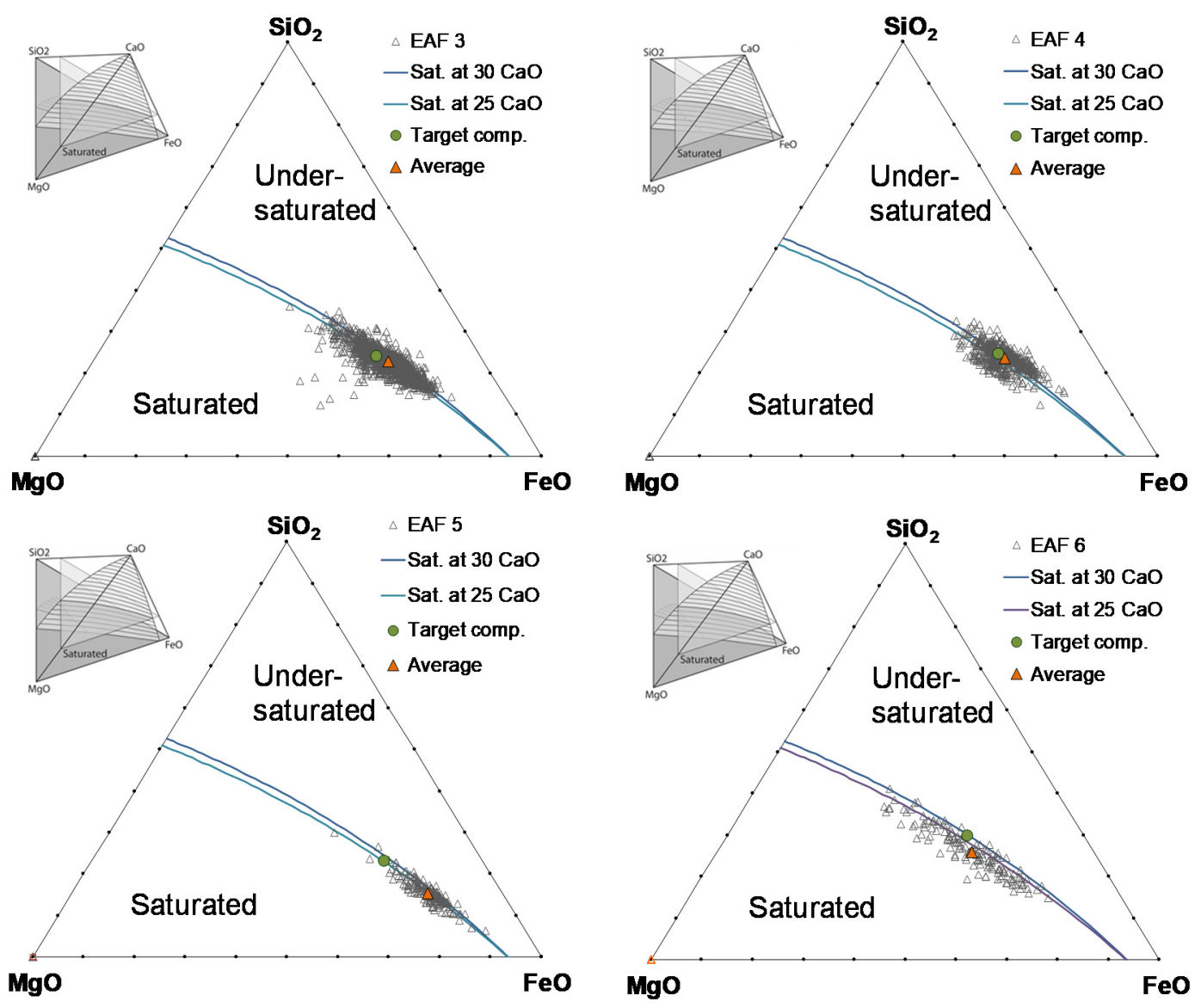

Figure 5. Distribution of slag analysis data from EAF heats for carbon steelmaking, in the system $\mathrm{CaO}-\mathrm{SiO}{ }_{2}-\mathrm{FeO}-\mathrm{MgO}-$ $5 \% \mathrm{Al}_{2} \mathrm{O}_{3}$; lines indicate $\mathrm{MgO}$ saturation at $25 \%$ to $35 \% \mathrm{CaO}$ and $1600{ }^{\circ} \mathrm{C}$.

The slag data of EAF 1 to EAF 6 in Figures 4 and 5 are very close to the $\mathrm{MgO}$ saturation surface, which is represented by saturation lines at $25 \% \mathrm{CaO}$ to $35 \% \mathrm{CaO}$, corresponding to the average $\mathrm{CaO}$ content of the slag data. In the case where the initial $\mathrm{MgO}$ content is lower than the saturation value, some $\mathrm{MgO}$ is dissolved from the EAF hearth and sidewall until the $\mathrm{MgO}$ saturation surface is reached. Some $\mathrm{MgO}$-oversaturated slags of EAF 3 are most likely related to losses of $\mathrm{MgO}$-based hearth repair mixes or sidewall gunning mixes after a preceding EAF refractory repair. EAF 6 applied mainly doloma as slag former, resulting in slightly $\mathrm{MgO}$-oversaturated slags.

The slag data from EAF 7 to EAF 10 in Figure 6 show a more pronounced scatter in composition. The increased standard deviation of slag compositions indicates lower process control: For example, an increased distribution in $\mathrm{FeO}$ content at controlled basicity indicates problems with the carbon-oxygen balance from the injectors and decreased efficiency of $\mathrm{FeO}$ reduction by injected carbon fines (e.g., EAF 6 to EAF 8 and EAF 10). EAF 8 was characterized by low slag control in $\mathrm{FeO}, \mathrm{SiO}_{2}$, and $\mathrm{MgO}$ due to unusually low input of lime/doloma blends, at $<25 \mathrm{~kg} / \mathrm{t}$. Then, the resulting unusual low slag mass was subject to increased compositional shifts due to usual scrap residues, losses of $\mathrm{MgO}$ repair mixes, and overoxidation of the slag (EAF 8).

Some EAF processes were characterized by mainly MgO-undersaturated slag compositions due to the application of lime or dolomitic lime as a slag former, with initial total $\mathrm{MgO}$ significantly lower than the saturation concentration, near $9 \% \mathrm{MgO}$ (Figure 6). Consequently, the slags showed $\mathrm{MgO}$ concentrations between the starting $\mathrm{MgO}$ content and $\mathrm{MgO}$ saturation depending on the $\mathrm{FeO}$ content, temperature, and process time (e.g., EAF 11 to EAF 13). Only mechanical losses of $\mathrm{MgO}$ repair mixes to the slag produced $\mathrm{MgO}$ concentrations that were higher than the MgO saturation (EAF 11 to EAF 13). 

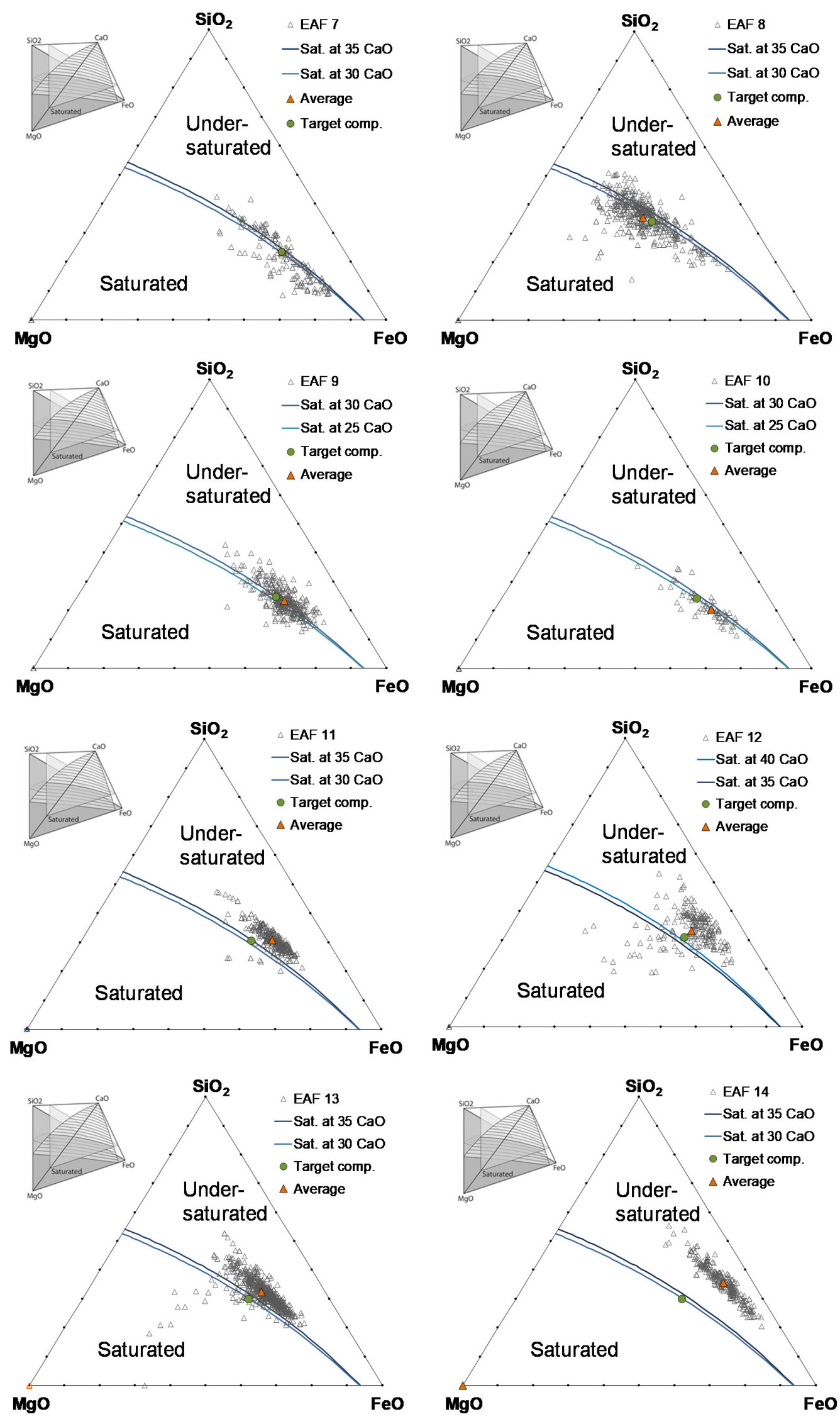

Figure 6. Distribution of slag analysis data from EAF heats for carbon steelmaking, in the system $\mathrm{CaO}-\mathrm{SiO} 2-\mathrm{FeO}-\mathrm{MgO}$; lines indicate $\mathrm{MgO}$ saturation at $30 \%$ to $40 \% \mathrm{CaO}$ and $1600{ }^{\circ} \mathrm{C}$. 
EAF 14, however, operated systematically at MgO-undersaturated conditions, obviously with a certain control on $\mathrm{MgO}$ losses. As lime was applied as the only slag former, the tapped $\mathrm{MgO}$ content represents an approximately $1.7 \% \mathrm{MgO}$ pick-up from the lining, however controlled, due to the rather short process time of a continuously charged EAF.

\section{Discussion}

The usefulness of the proposed $\mathrm{MgO}$ saturation diagram in Figure 2 was shown by applying large data sets of analyzed slag samples from industrial EAF production in Figures 4-6. Important information about the $\mathrm{MgO}$ saturation status of the slags and its control by production management can be derived from the distribution of the data with respect to the $\mathrm{MgO}$ saturation surface in the complex compositional space. In contrast, pointwise calculation of $\mathrm{MgO}$ saturation levels for the average composition or every single slag composition from other $\mathrm{MgO}$ saturation models is less informative for large datasets.

Saturation with $\mathrm{Ca}$ silicates occurs only at rather low $\mathrm{FeO}$ content, e.g., in some $\mathrm{Cr}_{2} \mathrm{O}_{3}$-containing stainless steelmaking slags. $\mathrm{Mg}_{2} \mathrm{SiO}_{4}$ forsterite occurs only below $25 \%$ $\mathrm{CaO}$ (shown as light gray lines in the Figure 2 tetrahedron). These conditions are usually not both realized in industrial EAF slags for carbon steelmaking. Concepts of double saturation with $\mathrm{C}_{2} \mathrm{~S}$ (e.g., $\left.[4,5,12]\right)$ are of no importance for usual carbon steelmaking EAF slags. Therefore, $\mathrm{MgO}$ saturation was the only stability field considered here for EAF slags, bearing in mind its importance for good slag foaming and minimum refractory corrosion.

It is interesting to note that the average slag compositions for, e.g., EAFs 7, 8, 12, and 13 with low control over slag operation were still close to $\mathrm{MgO}$ saturation. However, $\mathrm{MgO}-$ undersaturated slag data indicated heats with (1) lower slag foaming and, depending on the slag volume, (2) increased radiation losses to the EAF walls and (3) increased corrosion potential of the $\mathrm{MgO}$ lining. The diagram presented in Figure 3 is helpful in indicating the share of inappropriate heats and providing initial information about the particular EAF control problem.

The desired $\mathrm{MgO}$ saturation levels (the proposed "target" composition in Figures 4-6) are defined with respect to particular EAFs and steel plant conditions, i.e., depending on the particular FeO levels and available raw materials. In the proposed representation of the $\mathrm{MgO}$ saturation surface, the $\mathrm{MgO}$ saturation conditions were investigated and defined independently from standard basicity concepts for EAF steelmaking. This might be of interest when considering EAF process slags in other oxide systems, e.g., for Cr stainless steelmaking or non-ferrous metal production.

\section{Conclusions}

Control of the slag composition in general and $\mathrm{MgO}$ saturation in particular plays an important role in energy-efficient EAF processing with minimum losses of iron and alloys to the tapped slag.

The application of phase equilibrium diagrams derived from internally consistent databases for steelmaking slags has been established as a common tool for interpreting plant or laboratory data with respect to saturation conditions. A diagram based on thermochemical calculations [32] was presented in this study, focused on $\mathrm{MgO}$ saturation in the system $\mathrm{CaO}-\mathrm{MgO}-\mathrm{FeO}-\mathrm{SiO}_{2}-5 \% \mathrm{Al}_{2} \mathrm{O}_{3}$ and rather close to the real EAF slag compositions. Examples were shown for large datasets from 14 EAFs for carbon steelmaking, indicating that the proposed diagram is suited to interpreting data sets from industrial EAF slag samples for process optimization.

Deeper analysis for different groups of heats (e.g., those with different steel grades or different raw materials) is evidently required for improved EAF slag and operation control, e.g., [19], but not shown here due to the focus on the general applicability of the proposed $\mathrm{MgO}$ saturation diagram.

The diagram might be applied to monitor regularly or even on-line the particular slag operation with respect to $\mathrm{MgO}$ saturation and $\mathrm{FeO}$ control. 
Funding: This research received no external funding. The APC was funded by the German Research Foundation (DFG) and the University of Bayreuth in the funding programme Open Access Publishing.

Acknowledgments: A previous version of the model was developed and published within RHI Magnesita [19]. Here we present an improved version, more profound theoretical basis, significantly more illustrations, and implications. Support for metallurgical process optimization in EAF, etc., is available from the RHI Magnesita process group.

Conflicts of Interest: The author declares no conflict of interest.

\section{References}

1. World Steel Association, Statistical Yearbooks 1991 to 2020. Available online: http:/ / www.worldsteel.org (accessed on 10 November 2020).

2. Ito, K.; Fruehan, R.J. Slag foaming in smelting reduction processes. Steel Res. 1989, 60, 151-156. [CrossRef]

3. Reisinger, P.; Presslinger, H.; Hiebler, H.; Zednicek, W. MgO-Löslichkeit in Stahlwerksschlacken (Dissolution of MgO in steelmaking slags). Berg und Hüttenmännische Zeitschrift 1999, 144, 196-203.

4. Pretorius, E.B.; Carlisle, R. Foamy slag fundamentals and their practical application to electric furnace steelmaking. Iron Steelmak. 1999, 26, 79-88.

5. Pretorius, E.B. Slag Fundamentals. An Introduction to the Theory and Practice of EF Steelmaking. Iron Steel Soc. 1998, 26, 79-88.

6. Assis, A.N.; Tayeb, M.A.; Sridhar, S.; Fruehan, R.J. Phosphorus equilibrium between liquid iron and $\mathrm{CaO}-\mathrm{SiO}{ }_{2}-\mathrm{MgO}_{-} \mathrm{Al}_{2} \mathrm{O}_{3}-\mathrm{FeO}-$ $\mathrm{P}_{2} \mathrm{O}_{5}$ Slags: EAF slags, the effect of alumina and new correlation. Metals 2019, 9, 116. [CrossRef]

7. Sarma, B.; Cramb, A.W.; Fruehan, R.J. Reduction of FeO in smelting slags by solid carbon: Experimental results. Metall. Mater. Trans. B 1995, 27, 717-730. [CrossRef]

8. Vieira, D.; Montecinos de Almeida, R.A.; Bielefeldt, W.V.; Faria Vilela, A.C. Slag Evaluation to Reduce Energy Consumption and EAF Electrical Instability. Mater. Res. 2016, 19, 1127-1131. [CrossRef]

9. Morales, R.D.; Lule, R.G.; Lopez, F.; Camacho, J.; Romero, J.A. The Slag Foaming Practice in EAF and Its Influence on the Steelmaking Shop Productivity. ISIJ Int. 1995, 35, 1054-1062. [CrossRef]

10. Zhang, Y.; Fruehan, R.J. Effect of gas type and pressure on slag foaming. Metall. Mater. Trans. B 1995, 26, 1088-1091. [CrossRef]

11. Ghag, S.S.; Hayes, P.C.; Lee, H.G. Model development of slag foaming. ISIJ Int. 1998, 38, 1208-1215. [CrossRef]

12. Heo, J.H.; Park, J.H. Assessment of Physicochemical Properties of Electrical Arc Furnace Slag and Their Effects on Foamability. Metall. Mater. Trans. B 2019, 50, 2959-2968. [CrossRef]

13. Wu, L.S.; Albertsson, G.J.; Sichen, D. Modelling of slag foaming. Ironmak. Steelmak. 2010, 37, 612-619. [CrossRef]

14. Seetharaman, S.; Teng, S.; Hayashi, M.; Wang, L. Understanding the Properties of Slags. ISIJ Int. 2013, 53, 1-8. [CrossRef]

15. Park, Y.; Min, D.J. Foaming Index of CaO-SiO2-FeO-MgO Slag System. Advances in Molten Slags, Fluxes, and Salts. In Proceedings of the 10th International Conference on Molten Slags, Fluxes and Salts (MOLTEN16), TMS (The Minerals, Metals \& Materials Society) Conference Proceedings, Seattle, WA, USA, 22-25 May 2016; pp. 607-615.

16. Fruehan, R.J.; Li, Y.; Brabie, L. Dissolution of Magnesite and Dolomite in Simulated EAF Slags. In Proceedings of the ISSTech 2003, Iron \& Steel Society International Technology Conference and Exposition, Indianapolis, IN, USA, 27-30 April 2003; pp. 799-812.

17. Bygdén, J.; DebRoy, T.; Seetharaman, S. Dissolution of $\mathrm{MgO}$ in stagnant $\mathrm{CaO}-\mathrm{FeO}-\mathrm{SiO}_{2}$ slags. Ironmak. Steelmak. 1994, 21, 318-323.

18. Song, S.; Zhao, J.; Pistorius, P.C. MgO refractory attack by transient non-saturated EAF slag. Metall. Mater. Trans. B 2020, 51B, 891. [CrossRef]

19. Kirschen, M.; Hanna, A.; Zettl, K.M. Improvement of EAF Process and Refractory Consumption by Advanced Slag Modeling. Iron Steel Technol. 2016, 13, 52-59.

20. López, F.; Farrando, A.; López, M.; Picco, L.; Loeffelholz, M. Slag modeling for optimizing the use of fluxes in a DRI-based steelmaking operation. In Proceedings of the AISTech 2016, Association for Iron and Steel Technology Conference Proceedings, Pittsburgh, PA, USA, 16-19 May 2016; pp. 875-880.

21. Avelar, T.C.; Fardin Grillo, F.; Junca, E.; Coleti, J.L.; de Oliveira, J.R. Evaluation of recycled MgO-C bricks and dead-burned dolomite fines in setting slag foaming in the electric arc furnace. REM Int. Eng. J. 2018, 71, 67-74. [CrossRef]

22. Luz, A.P.; Leite, F.C.; Brito, M.A.M.; Pandolfelli, V.C. Slag conditioning effects on MgO-C refractory corrosion performance. Ceram. Int. 2013, 39, 7507-7515. [CrossRef]

23. Schürmann, E.; Kolm, I. Mathematische Beschreibung der MgO-Sättigung in komplexen Stahlwerksschlacken beim Gleichgewicht mit flüssigem Eisen (Mathematical modelling of $\mathrm{MgO}$ saturation in complex steeelmaking slags at equilibrium with liquid iron). Steel Res. Int. 1986, 57, 7-12. [CrossRef]

24. Park, J.M.; Lee, K.K. Reaction equilibria between liquid iron and CaO-Al2O3-MgOsat-SiO2-FetO-MnO-P2O5 slag. In Proceedings of the 79th Steelmaking Conference, Pittsburgh, PA, USA; 1996; pp. 165-172.

25. Park, J.M. MgO solubility in BOF slag equilibrated with ambient air. Steel Res. Int. 2001, 72, 141-145. [CrossRef]

26. Tayeb, M.A.; Assis, A.N.; Sridhar, S.; Fruehan, R.J. MgO Solubility in Steelmaking Slags. Metall. Mater. Trans. B 2015, 46B, 1112-1114. [CrossRef]

27. Jung, S.M.; Rhee, C.H.; Min, D.J. Solubility of MgO in CaO-based slags. In Proceedings of the Procemin 2008, V International Mineral Processing Seminar, Santiago, Chile, 22-24 October 2008; pp. 133-142. 
28. Brüggmann, C.; Pötschke, J. MgO Saturation in Secondary Metallurgical Lime-aluminate and Lime-silicate Slags. Steel Res. Int. 2011, 82, 422-427. [CrossRef]

29. Kwong, K.S.; Bennet, J.; Krabbe, R.; Petty, A.; Hugh, T.H. Thermodynamic Calculations Predicting MgO Saturated EAF Slag for Use in EAF Steel Production. Materials Characterization, Computation and Modeling. In TMS (The Minerals, Metals E Materials Society) Conference Proceedings; John Wiley and Sons: Hoboken, NJ, USA, 2009; pp. 63-70.

30. Bennet, J.; Kwong, K.S. Thermodynamic studies of MgO saturated EAF slag. Ironmak. Steelmak. 2010, 37, 529-535. [CrossRef]

31. Montecinos de Almeida, R.A.; Vieira, D.; Bielefeldt, W.V.; Faria Vilela, A.C. MgO Saturation Analysis of CaO-SiO $2-\mathrm{FeO}-\mathrm{MgO}-$ $\mathrm{Al}_{2} \mathrm{O}_{3}$ Slag System. Mater. Res. 2017, 21. [CrossRef]

32. Bale, C.W.; Bélisle, E.; Chartrand, P.; Decterov, S.A.; Eriksson, G.; Gheribi, A.E.; Hack, K.; Jung, I.-H.; Kang, Y.-B.; Melançon, J.; et al. FactSage Thermochemical Software and Databases 2010-2016. Calphad 2016, 54, 35-53. [CrossRef]

33. Morales, A.T.; Fruehan, R.J. Thermodynamics of MnO, FeO, and Phosphorus in Steelmaking Slags with High MnO Contents. Metall. Mater. Trans. B 1997, 28B, 1111-1118. [CrossRef]

34. Mombelli, D.; Mapelli, C.; Barella, S.; Gruttadauria, A.; Sosio, R.; Valentino, G.; Ancona, V. Model for Phosphorus Removal in LD Converter and Design of a Valuable Operative Practice. Steel Res. Int. 2018, 89, 1700467. [CrossRef] 